\title{
MARY MIDGLEY E RICHARD DAWKINS: SEMELHANÇAS E DESSEMELHANÇAS
}

\author{
André Assi Barreto*
}

\begin{abstract}
Resumo: A aspiração deste artigo é estabelecer uma comparação entre o pensamento de Mary Midgley (1919- ) e de Richard Dawkins (1941-), introduzir brevemente às ideias dos dois e mostrar o porquê das diferenças entre eles, mesmo sabendo que ambos partem de uma ideia comum: a teoria sintética da evolução. A teoria da evolução darwiniana por seleção natural é uma excelente maneira para responder às perguntas nucleares da existência humana (Midgley, 1983), mas Dawkins e Midgley traçam trilhas diferentes em suas respostas. Aqui os comparamos quanto a dois pontos em especial: a interpretação teleológica da evolução e o problema do gene egoísta.
\end{abstract}

Palavras-chave: Filosofia, Ciência, Moral, Dawkins, Mary Midgley.

Abstract: The aim of this article is to estabilish a comparison between the thought of Mary Midgley (1919- ) and Richard Dawkins (1941- ), briefly introduce the ideas of the two and show the reason of their differences, even knowing that both start of a common idea: the synthetic theory of evolution. Darwinian theory of evolution by natural selection is an excellent way to respond the nuclear questions of human existence (Midgley, 1983), but Dawkins and Midgley trace different paths in their answers. Here we compare them based in two points of view: the teleologic interpretation of evolution and the problem of the selfish gene.

Keywords: Philosophy. Science. Moral. Dawkins. Mary Midgley.

* Graduando em Filosofia pela Universidade São Judas Tadeu. O presente artigo é resultado final de iniciação científica, modalidade PIBIC (fomentado pelo CNPq, ao qual agradecemos), desenvolvida entre o segundo semestre de 2010 e o primeiro de 2011, sob a orientação da Profa. Dra. Regina André Rebollo. E-mail: andre.assibarreto@gmail.com 
$\mid 308$ |

Mary Midgley e Richard Dawkins: semelhanças ...

Neurath comparou a ciência a um barco que, se fôssemos reconstruir, deveríamos fazê-lo tábua por tábua, permanecendo dentro dele enquanto flutua. O filósofo e o cientista estão no mesmo barco...

W. Quine, Word and Object, 1960.

\section{Introdução}

Mary Midgley é uma filósofa inglesa, professora sênior aposentada da Universidade de Newcastle em Tyne. Lecionou filosofia da ciência, mas sua atual área de interesse é a filosofia moral, com ênfase nas reflexões envolvendo os animais. Midgley teve sua produção intelectual iniciada quando já era quinquagenária. Grande parte de seus interesses se concentra no problema da natureza humana e nas suas implicações para a vida moral; ao longo de seus escritos, visa fugir das tradicionais dicotomias razão/emoção, mente/corpo e alma/matéria, que percorrem a história da filosofia. Midgley é uma filósofa pouco conhecida, por ter uma reflexão bastante recente e ainda não ter sido traduzida para o português; também não existem comentários às obras de Midgley, apenas embates com pensadores de maior renome (como Dawkins) e parcerias com outros filósofos, como a compilação do Compemdio de Ética junto a Peter Singer. Richard Dawkins é um renomado zoólogo britânico, popularizador da ciência (em 1996 recebeu da universidade de Oxford o prêmio da cátedra Simonyi de "professor de Compreensão Pública da Ciência"), evolucionista e, mais recentemente, militante ateísta ${ }^{1}$. O pensamento de Dawkins é marcado pelo darwinismo, não apenas como forma de explicar

\footnotetext{
${ }^{1}$ Dawkins sempre (desde sua adolescência) foi ateu, porém o ateísmo nunca foi a tônica de suas obras, apesar de flertar com o assunto em praticamente todas elas a partir de O Relojoeiro Cego (1986). A militância de Dawkins ganhou corpo com o sucesso de Deus, um delírio (2006). Até então Dawkins e seus editores temiam que o assunto não tivesse mercado editorial. Uma crítica interessante ao assunto pode ser observada em McGrath \& McGrath (2007) e em McGrath (2008).
} 
a complexidade da vida na terra, mas como uma cosmovisão; isso pode ser compreendido pela ideia de que o darwinismo não é apenas uma maneira de explicar a vida, mas também a cultura e todo o resto. Isso é bem ilustrado pelo conceito de meme, o "gene (replicador biológico) da cultura" - um replicador cultural. Segundo Dawkins (2010), Blackmore (1999) e Dennett (1998), os elementos culturais (músicas, expressões, estilos de vestimenta etc) são memes, que estão sujeitos à mesma dinâmica seletiva que os genes; memes fortes prosperam e sobrevivem, memes fracos desaparecem da cultura rapidamente. A metáfora proposta por Dennett para ilustrar o darwinismo universal (Dennett, 1998) é de que o darwinismo deve ser visto como uma espécie de ácido universal que corrói tudo, especialmente as ideias da tradição. Trata-se do darwinismo encarado como uma teoria capaz de explicar todas as coisas - seu surgimento, comportamento e extinção; o darwinismo seria o santo graal da ciência, a chave para a explicação de tudo. Midgley é uma crítica feroz dessa cosmovisão, bem como da hipótese de uma evolução memética da cultura (Midgley, 2000, pp. 79-100).

Dawkins é tanto admirado quanto criticado por ser um divulgador da ciência tão voraz. O New York Times disse, certa vez, que Dawkins faz de seus leitores, mesmo os sem formação científica, gênios (Mccrath, 2008); já seus detratores o consideram intolerante e cientificista. Dawkins está inserido em uma corrente dentro da Biologia denominada neodarwinismo, que é um contraponto ao darwinismo clássico - que considerava o indivíduo como a unidade de seleção - e ao darwinismo moderno - que considera a espécie (ou seu grupo) como a unidade de seleção. O neodarwinismo desloca do indivíduo e da espécie para o gene a unidade de seleção (Waizbort, 2003). Embora este seja o aspecto do neodarwinismo que nos interessa aqui, não afirmamos que ele se reduz exclusivamente a este aspecto, o neodarwinismo é um movimento surgido na Biologia após a segunda síntese, entre os anos de 1940 e 1950, encabeçado por biólogos como Haldane, Dobzhansky, Mayr, Julian Huxley e outros. 
$|310|$

Mary Midgley e Richard Dawkins: semelhanças ...

Consideramos de suma importância comparar estes dois pensadores, pois se trata, em nosso entender, de estabelecer um diálogo positivo e frutífero entre filosofia e ciência, especialmente tendo em vista que ambos, apesar de parte das vezes chegarem a conclusões diferentes, partem do mesmo ponto: a teoria sintética da evolução, ou seja, a evolução tal como proposta por Darwin, somada à genética de Mendel. Os interesses de ambos convergem para as questões da etologia (comportamento animal), dos escritos de Darwin e das implicações morais da teoria da evolução por seleção natural. Embora seus interesses sejam convergentes, ambos têm concepções diferentes tanto de ciência como das possíveis implicações - resvalem elas ou não na moralidade - da evolução na vida das pessoas. A questão com que ambos estão preocupados é mostrar o papel do homem na natureza e os dois consideram a seleção natural de Darwin como uma importante ferramenta para que isso seja feito (Midgley, 1983) ${ }^{2}$.

Trataremos então, dentre as possíveis semelhanças e dessemelhanças entre Midgley e Dawkins, da interpretação teleológica da evolução - a saber - a ideia de que a evolução tem uma finalidade preestabelecida e que o processo evolutivo por seleção natural, ao chegar ao Homo Sapiens teria atingido seu ápice, ou seja, todo o processo evolutivo se deu, na verdade, para que o homem viesse à existência. Os dois discordam dessa posição, Dawkins trata dela em seu A Grande História da Evolução, no capítulo que antecede a todos os contos ${ }^{3}$. Dawkins chama essa

\footnotetext{
${ }^{2}$ Muito embora esse seja um dos objetivos com o artigo, não pretendemos sustentar a insipiente afirmação de que as tarefas do filósofo e do cientista se confundem. Apenas queremos mostrar que, a despeito do que crê o senso comum, filósofo e cientista podem trabalhar em conjunto, com cada um realizando a tarefa que lhe cabe e reconhecendo que o trabalho de um requer o do outro.

${ }^{3}$ Preciosidade que se perdeu na tradução brasileira, que optou por traduzir o título original The Ancestor's Tale - O Conto do Ancestral - por A Grande História da Evolução.
} 
interpretação de "arrogante" 4 e Midgley o ponto de vista em seu clássico Beast and Man, mais especificamente no primeiro tópico do capítulo 7, onde a filósofa diz que não estamos autorizados a falar em termos de espécies superiores ou inferiores e nem que a evolução teria falhado se o homem não tivesse evoluído. Tratamos dessa questão com vagar na primeira parte (I - A evolução tem um fim?) deste artigo.

Na parte seguinte (II - São nossos genes egoístas?) mostraremos o embate público entre Dawkins e Midgley que se tornou uma peça polêmica, e em certos sentidos, confusa em termos científicos (Mcgrath, 2008, p. 53), entre Dawkins e Midgley quanto ao conceito de gene egoísta, apresentado pela primeira vez no best-seller homônimo de Dawkins, publicado em $1976^{5}$.

${ }^{4}$ Essa ideia não faz parte apenas das interpretações das teorias da biologia, mas de maneira semelhante e até mesmo mais forte, da astronomia e da física; trata-se do denominado princípio antrópico forte (ou antropocêntrico, como sugere Sagan), a saber, a ideia de que, alteradas (sabe-se lá como isso seria possível) as leis e constantes da natureza (a carga do elétron, a constante de Planck, a atração gravitacional newtoniana e as demais constantes da física) a vida na Terra seria impossível, portanto, dada a observância de que as constantes são assim, elas devem ter sido "sintonizadas" por alguém (embora saibamos que esse alguém seja Deus, os proponentes do princípio não admitem isso abertamente) para propiciar a existência da vida (mormente a humana) na terra, visto que seus valores são deveras estreitos e qualquer oscilação mínima impossibilitaria o surgimento da vida. Dawkins trata disso em A Grande História da Evolução (Dawkins, 2009, pp. 18-20). Os proponentes de tal ideia desconsideram a possibilidade dos multiversos (milhões de universos paralelos com as mais diversas constantes, descartam uma mudança de ponto de vista: talvez as leis não existam para propiciar nossa existência, mas nossa existência tenha vindo à tona simplesmente porque as constantes são assim, caso elas fossem diferentes, simplesmente não estaríamos aqui. Uma crítica mais aprofundada ao princípio antrópico forte pode ser encontrada em Dawkins (2006); Sagan 1996 e em especial Stenger (2004).

${ }^{5} \mathrm{O}$ livro ganhou um novo prefácio em 2005 (publicado em português pela Companhia das Letras em 2010) dedicado a explicar melhor os motivos 
$\mid 312$ |

Mary Midgley e Richard Dawkins: semelhanças ...

Midgley publicou uma crítica na revista Philosophy chamada "Gene-Juggling" onde diz que a análise de Dawkins é reducionista e antropomórfica e que, na verdade, ela atrapalha a compreensão da evolução e do papel do homem na terra à luz da teoria darwiniana (Midgley, 1979), o que, a despeito das discordâncias, é a intenção de ambos. Faremos a defesa de Dawkins com base tanto no artigo (também publicado na Philosophy) que foi uma réplica pontual a Midgley, o "In Defence of Selfish Genes" (Dawkins, 1981) quanto no seu novo prefácio ao O Gene Egoísta, onde o zoólogo aclara uma série de mal-entendidos (entre eles, os ocasionados pelas críticas de Midgley).

Por último, faremos uma breve conclusão, enfatizando a necessidade e possibilidade de diálogos salutares - mesmo havendo divergências - entre ciência e filosofia e defenderemos que, no todo da obra, o pensamento de Dawkins e Midgley podem tomar uma direção de complementação um ao outro e não de conflito aberto e irreconciliável.

\section{A evolução tem um fim?}

Não só dá-se aqui pela primeira vez um golpe mortal na 'teleologia' das ciências naturais, como se explica empiricamente o significado racional delas" Marx após ler A Origem das Espécies ${ }^{6}$

O processo lento e gradual ${ }^{7}$ que gerou a diversidade atual da vida, os bilhões de espécies, - muitas das quais os cientistas ainda nem mesmo computaram ou deram um nome - tem um

que o levaram a falar em gene egoísta, o que rendeu tantos malentendidos e interpretações aberrantes, inclusive, em nosso entender, a de Mary Midgley.

${ }^{6}$ Citação indireta retirada de (Rachels, 1990, p. 110).

${ }^{7}$ Quanto a ser ou não gradual, a controvérsia permanece no meio acadêmico da Biologia. Dawkins é um proponente do chamado "gradualismo", a ideia que a evolução se deu de maneira gradual, ao longo dos bilhões de anos de idade do planeta; se contrapõe ao "equilíbrio 
sentido, direção, propósito, ou na linguagem dos filósofos, um télos? Em que medida podemos dizer, se é que podemos, que o processo denominado evolução por seleção natural, ocorrido em bilhões de anos é, na verdade, uma escada de desenvolvimento, onde a espécie do degrau acima é, de alguma forma, "superior" à do degrau abaixo, e esta última sendo, portanto, "inferior"; e além disso haveria um último degrau a ser galgado, onde a evolução atingiria seu ápice? Se sim, quem imprimiu tal télos na natureza? Como diz Midgley: "É difícil ver a quem creditaríamos tal propósito, a menos que invoquemos Deus" (Midgley, 2002, p. 139, tradução nossa). E como Deus não é uma boa resposta para nenhuma boa pergunta, nem Midgley e tampouco Dawkins a adotaram.

Midgley coloca a questão em outros termos: "Haveria algo de errado se, por exemplo, pássaros ou formigas, cobras ou pessoas nunca tivessem se desenvolvido?" (Midgley, 2002, p. 139, grifo e tradução nossos). Haveria algo de "errado" com a evolução se a nossa espécie, se o Homo Sapiens, não tivesse evoluído? Teria a evolução falhado caso isso tivesse ocorrido? Essa é, de fato, a preocupação daqueles que refletem sobre esse problema, se de alguma forma a evolução reserva algo especial para a nossa própria espécie. A resposta tanto de Midgley quanto de Dawkins é não; vejamos com mais vagar o tratamento que ambos dão à questão.

Demos, na citação anterior, ênfase na palavra "pessoas" pois existe uma interpretação corrente, como bem coloca Dawkins em seu A Grande História da Evolução, que concebe as pessoas como a finalidade última da evolução, essa interpretação é bastante popular e é comumente expressa na imagem (contida nos manuais) de uma fileira de símios, onde os primeiros possuem uma postura quadrúpede, os medianos possuem a coluna curvada até que chegamos ao gênero Homo e acaba então, "perfeitamente", em nós, agricultores:

pontuado" proposto pelo já falecido colega de Dawkins, Stephen Jay Gould. Para compreender a posição gradualista de Dawkins, sugerimos Dawkins, (1998) e o livro de Kim Sterelny "Dawkins vs. Gould: Survival of the Fittest" (2001), para compreender as diferenças entre os dois. 
$|314|$

Mary Midgley e Richard Dawkins: semelhanças ...

(...) é a de uma fila de ancestrais simiescos a andar desajeitadamente, ascendendo na esteira da majestosa figura que os encabeça num andar ereto e vigoroso: o Homo Sapiens Sapiens - o homem como última palavra da evolução (e nesse contexto é sempre um homem, e não uma mulher), o homem como o alvo de todo o empreendimento, o homem como um magneto, atraindo a evolução do passado em direção à proeminência (Dawkins, 2009, p. 18).

Dawkins considera essa interpretação arrogante, daí a chamar o capítulo de seu livro em que trata disso de "a arrogância da interpretação a posteriori” (Dawkins, 2009, p. 17). Segundo Dawkins, essa é uma concepção - até mesmo da história em geral ${ }^{8}$ - bastante arraigada, que tem "a soberba de achar que o passado teve por objetivo o tempo atual" (Dawkins, 2009, p. 17) e é contra ela como um todo que Dawkins está argumentando em seu livro, daí o fato de seus contos começarem pelo homem moderno, o agricultor e terminarem no conto da Taq, uma bactéria9 A preocupação de Dawkins é, especialmente com a ideia de que a evolução teria de culminar no homem, estaria de alguma forma,

8 Tal concepção também aparece na literatura filosófica, em Kant, por exemplo. Na primeira proposição de seu Ideia de uma História Universal de um Ponto de Vista Cosmopolita, Kant considera impossível obter um conhecimento seguro das coisas, sem ao menos a pressuposição de que a natureza segue algum fim: "Todas as disposições naturais de uma criatura estão destinadas a um dia se desenvolver completamente e conforme um fim. Em todos os animais isto é confirmado tanto pela observação externa quanto pela interna ou anatômica. Um órgão que não deva ser usado, uma ordenação que não atinja o seu fim são contradições à doutrina teleológica da natureza. Pois, se prescindirmos desse princípio, não teremos uma natureza regulada por leis, e sim um jogo sem finalidade da natureza e uma indeterminação desconsoladora toma o lugar do fio condutor da razão." (Kant, 2011, p. 5, grifos do autor).

9 Taq, abreviação de Thermus aquaticus, é uma bactéria do tipo eubactéria hipermófila. É cara aos biólogos por ser a fonte da enzima da duplicação do DNA. Para mais detalhes sobre ela e sobre o porquê dela ter sido a escolhida para ganhar o último conto, Cf. (Dawkins, 2009, p. 636). 
dirigida para isso: propiciar a existência humana. A arrogância de considerar que todos os nossos antepassados não passam de rascunhos ou esboços de seres humanos, quase humanos. As imagens providas por Carl Sagan em Pálido Ponto Azul são de grande valia para ilustrar como essa concepção permeia o senso comum:

\begin{abstract}
Na cultura popular, adota-se a posição oposta, também induzida pelo chauvinismo humano (e pela falta de imaginação): as histórias infantis e os desenhos animados fazem os animais vestir roupa, morar em casas, usar garfo e faca, e falar. Os três ursos dormem em camas. A coruja e o gatinho vão à praia num belo barco verde-amarelo. As mães dinossauros acariciam os filhotes. Os pelicanos entregam cartas. Os animais de estimação têm nomes humanos. Bonecas, quebra-nozes, xícaras e pires dançam e têm opiniões. Na série Thomas the tank engine, vemos até locomotivas e vagões antropomórficos, representados com muito encanto. Seja qual for o objetivo de nosso pensamento, animado ou inanimado, tendemos a lhe atribuir traços humanos. Não podemos evitar. As imagens logo acodem à mente. As crianças são apaixonadas por elas (Sagan, 1996, p. 57).
\end{abstract}

O senso comum tende a pensar que, se não for humano, não é bom e que tudo que não é humano, gostaria de sê-lo.

Dawkins escreve um livro para fugir dessa concepção tão comum; Midgley foge dessa ideia munida do conhecimento que a etologia - estudo do comportamento animal - lhe forneceu na década de 1970. Na busca por um critério que mostrasse onde está a tão aclamada superioridade não só do homem sobre as outras formas de vida não humanas, mas de determinadas espécies não humanas sobre outras, Midgley mostra que espécies consideradas inferiores sobrevivem, se comunicam, são inteligentes e/ou são tão complexas quanto os homens. Onde estaria a superioridade então? 
$|316|$

Mary Midgley e Richard Dawkins: semelhanças ...

Se o homem deve ser considerado superior por ter sobrevivido a um processo de certa maneira cego, por que não considerar o mesmo para todos os outros animais que sobreviveram? O que dizer das amebas, que não só sobreviveram, como praticamente conservam todo o DNA de seus ancestrais? Vejamos as palavras de Midgley:

(...) O que há de descendente [downward] na tendência que produziu elefantes, chimpanzés, lobos, golfinhos e gralhas em comparação com a que produziu formigas e abelhas? Neste gráfico, o sentido ascendente só pode representar um único valor: harmonia. Não pode ser uma questão apenas de sobrevivência, nem mesmo termos numéricos. A sobrevivência também é atingida por criaturas muito menos ambiciosas que ocorrem em número elevado. (De fato, um gene consciente de custobenefício que realmente compreendesse seu negócio teria, sem dúvida, permaneceria à bordo de algo como uma ameba, ele provavelmente estaria entre os últimos a partirem). Tampouco é uma questão de sobrevivência-como-uma- sociedade, já que muitos animais atingem isso, apesar de muita disputa (Midgley, 2002, p. 142, tradução nossa e grifo da autora).

Ou seja, a sobrevivência não é um critério forte o suficiente para dizer que uma espécie é superior à outra, nem mesmo em termos numéricos. A menos que todos estejam dispostos a considerar uma ameba como uma das formas mais "elevadas" de vida na terra a admitir que ela seria a forma de vida a que todos aspiram (Midgley, 2002, p. 144).

Tampouco a complexidade cumpre essa função ${ }^{10}$. Se assim fosse, águas-vivas e não homens ocupariam o último degrau da

10 Aclaramos que isso só é verificado se acompanharmos toda a argumentação de Midgley. Mas permanece a necessidade de uma 
escada evolutiva: nesse quesito "os cupins estão no alto, e algumas das colônias de águas-vivas como o Caravela Portuguesa (portuguese man of war) ${ }^{11}$, parecem invencíveis" (Midgley, 2002, p. 144, tradução nossa). Por incrível que pareça, a inteligência também não é capaz de dar conta desse problema:

\begin{abstract}
Atualmente, a sugestão favorita para essa propriedade é a inteligência, e é isso que faz a sugestão de Wilson tão interessante. Ela põe abelhas e formigas como as mais elevadas, atrás apenas do homem, apesar de sua falta de inteligência - apesar ainda, de apontar essa falta como a que as levaram a uma parada na evolução "há uns 50 ou 100 milhões

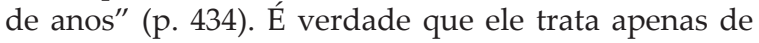
evolução social. Mas como alguém pode isolar isso? Falar da "evolução das sociedades" sem qualquer referência às mudanças nos tipos de indivíduos que a compõem é abstrair um conjunto de padrões que demandam atenção e aprovação num sentido que necessita de justificativa. (Midgley, 2002, pp. 145-146, tradução nossa e grifos da autora).
\end{abstract}

Ainda, nem mesmo a comunicação é um padrão infalível que nos dá uma resposta segura: “Como temos certeza que ela é uma excelência? É de fato claro que realmente superamos os corais e as colônias de águas-vivas? Com ela, não existem barreiras internas, a informação flui livremente de uma unidade a outra

definição de complexidade e é possível lançar a pergunta se o estágio de complexidade atingido pelo cérebro do Homo Sapiens não seria um elemento definitivo para colocar o homem como mais complexo e, ergo, "superior". ${ }^{11} \mathrm{O}$ animal a que Midgley se refere - The Portuguese Man of War - tem por nome científico Physalia physalis, pertence ao filo dos cnidários e não é uma água-viva como se pensa, mas um organismo colonial. $\mathrm{O}$ "Man of War" é uma alusão ao navio exportador inglês do século XVI, chamado "man o' war". O "Portuguese" provém do fato do animal lembrar as caravelas portuguesas. 
$\mid 318$ |

Mary Midgley e Richard Dawkins: semelhanças ...

onde que seja preciso" (Midgley, 2002, p. 145, tradução nossa e grifos da autora).

O problema é que essa questão não é uma questão livre de preconceitos. Inferior ou superior, mais ou menos desenvolvido são conceitos relativos, que dependem de uma série de outros; ou nas palavras de Midgley: "Não estamos lidando com um problema neutro, antisséptico e livre de valores" (Midgley, 2002, p. 145, tradução nossa).

O ponto é que, como Dawkins coloca: "A evolução biológica não tem uma linha de descendência privilegiada, nem um fim projetado" (Dawkins, 2009, p. 21). As formigas, capazes de (à sua maneira) se comunicar e de formar uma sociedade organizada e complexa, tiveram seus antepassados submetidos ao mesmo processo que os nossos, é deveras arrogante considerar que somos superiores a elas, ou que somos, em algum sentido, a finalidade última da evolução e elas não. Seria antropomorfismo ${ }^{12}$ demais conceber tal escada evolutiva que culmina no homem. Midgley diz algo parecido: “É possível construir uma escala em que ursos polares se encontrem numa posição inferior a pólipos de coral, assim como é possível construir uma invertida" (Midgley, 2002, p. 145, tradução nossa), ou seja, os padrões que temos para fazer tais comparações são flexíveis.

Uma maneira bem-humorada de mostrar o caráter antropocêntrico dessa interpretação da evolução é relatado por Dawkins em A Grande História da Evolução, fazendo uma referência ao psicólogo evolucionista Steven Pinker:

Elaborando aqui uma fantasia de Steven Pinker, se os elefantes pudessem escrever a história, talvez retratassem a anta, o musaranho-elefante, o

\footnotetext{
${ }^{12}$ Fora do contexto evolutivo, a recusa desse sentimento antropocêntrico também faz parte da literatura filosófica, já estava, por exemplo, em Nietzsche: "Mas se pudéssemos pôr-nos de acordo com o mosquito, aprenderíamos então que ele também flutua pelo ar com esse pathos e sente em si o centro esvoaçante desse mundo." (Nietzsche, 2008, pp. 25-26, grifo nosso).
} 


\begin{abstract}
elefante-marinho e o macaco-narigudo como ensaios, principiantes ao longo da estrada principal da evolução da tromba, dando os primeiros passos sem que nenhum deles - sabe-se lá por que alcançasse verdadeiramente o sucesso: tão perto, e no entanto, tão longe. Os elefantes astrônomos talvez especulassem se, em algum outro mundo, existiriam formas alienígenas de vida que teriam atravessado o rubicão nasal e dado o salto final para a plena proboscitude (Dawkins, 2009, p. 23).
\end{abstract}

Ou seja, se elefantes, em vez de homens, contassem a história da evolução, certamente se colocariam como télos do processo e espécies semelhantes a eles como rascunhos de elefantes, constituiria também uma arrogância centrista desprovida de evidência.

Seja por constituir uma arrogância sem fundamento, seja por uma falta de critério, o ponto é que tanto Dawkins quanto Midgley estão de acordo quanto ao fato da evolução não ter uma direção preestabelecida e que o homem não é o seu ápice, portanto, não faz sequer sentido falar em espécies superiores ou inferiores a outras.

\title{
II. São nossos genes egoístas?
}

“(...) não há mais conexão entre um gene egoísta e um humano egoísta do que entre uma pedra e uma nuvem de chuva." R. Dawkins, Desvendado o Arco-Íris.

Antes de mostrarmos em que termos se dá o desacordo entre o pensamento de Midgley e Dawkins, tentaremos aclarar, de forma sucinta ${ }^{13}$ (para que o jargão biológico seja evitado)

${ }^{13}$ Para uma explicação mais abrangente (da qual, por uma questão de espaço, não podemos dar conta aqui), sugerimos, além da leitura do próprio Dawkins (Dawkins, 2010): Waizbort (2003, pp. 30-35); McGrath (2008, pp. 46-54); Dawkins (2009, pp. 271-300) e Bueno (2008, pp. 28-74). 
$|320|$

Mary Midgley e Richard Dawkins: semelhanças ...

o que é o conceito de gene egoísta, proposto por Dawkins pela primeira vez em 1976 e que ganhou inúmeros simpatizantes tanto da filosofia quanto da ciência, como Dennett (1998), Blackmore, (1999) e Ridley, (2000). Traremos aqui, daquilo que for de pertinência filosófica e de relevância para a compreensão da crítica proposta por Midgley.

O que Dawkins defende em O Gene Egoísta é, grosso modo, o seguinte: nós, indivíduos, somos feitos de replicadores biológicos, que têm como único propósito a sobrevivência. Replicadores são "coisas" que fazem cópias de si próprias; tal tarefa cabe aos genes (já que, como dissemos na introdução, a tradição da qual Dawkins faz parte desloca para o gene - e não mais para a espécie ou para o grupo - a unidade de seleção) ${ }^{14}$, que, por sua vez, são parcelas de DNA. Cabe ao DNA fazer com que as características dos sobreviventes se propague para gerações futuras, pois os veículos (indivíduos) têm uma vida curta demais para darem conta de tal tarefa, ao passo que o gene é quase imortal (Dawkins, 2010, p. 87). Somos máquinas guiadas por nossos genes, e o comportamento de tais genes é, além de competitivo, egoísta; graças a isso (mesmo que depois de, provavelmente, milhões de anos) estamos aqui. Esta exposição sintética é suficiente para compreender as críticas (especialmente as de cunho filosófico) que virão: a detecção de um comportamento tipicamente humano numa entidade não humana (antropomorfização do gene), a proposta de uma moral pautada na evolução, que a primeira vista basearia-se num egoísmo moral (onde, portanto, o império dos genes egoístas seria um fomento molecular que justificaria as mais variadas barbáries humanas), reducionismo genético, entre outras. A seguir, apresentaremos a crítica de Midgley de forma breve e focaremos nas considerações que defendem a posição de Dawkins. Para atender aos nossos fins, é suficiente compreender que a maneira com que Dawkins vê a teoria da evolução é a partir da sua tese do egoísmo gênico: a unidade de seleção é descolacada

${ }^{14}$ E esse é um dos motes dessa tradição, visto que enquanto espécies ou indivíduos não fazem cópias de si. 
para o gene, havendo um rompimento com a tradição. Esses genes são máquinas de replicação e seu modus operandi é egoísta.

Midgley dá início a sua resenha a O Gene Egoísta - "GeneJuggling" - deixando claro qual será a tônica de sua crítica à obra de Dawkins: "Genes não podem ser egoístas ou altruístas, não mais do que átomos possam ser ciumentos, elefantes possam ser abstratos ou biscoitos, teleológicos" (Midgley, 1979, tradução nossa). Essa afirmação, que abre o artigo de Midgley, mostra que a filósofa considera o conceito de gene egoísta de Dawkins um tipo de antropomorfismo. Genes não podem ser egoístas, na mesma medida que átomos não podem ser ciumentos, porque genes e átomos não são pessoas e apenas pessoas - ou ao menos organismos dotados de comportamento - podem ser egoístas ou ciumentos ${ }^{15}$.

A mais recente obra de Midgley, chamada The Solitary Self, trata justamente dessa questão. Para ela, o egoísmo que Dawkins está a defender não é original, mas remonta à tradição iniciada pelo filósofo Thomas Hobbes. O egoísmo filosófico proposto por Hobbes recebe, de acordo com Midgley, uma nova roupagem, dada pelos proponentes do neodarwinismo: aquilo que ela chama de uma nova forma de "individualismo" e de um "atomismo social" (Midgley, 2010, pp. 18-20). Um versão revisitada de um reducionismo cientificista radical. Na obra, Midgley explica que essa cosmovisão exagerada deve ser atribuída aos neodarwinistas e não ao próprio Darwin, que não considerava sua teoria como uma maneira de explicar todas as coisas ${ }^{16}$.

${ }^{15}$ Entretanto, genes podem sim, ter interesses. Ao menos de acordo com Dennett, que mostra isso de maneira interessante em seu A Perigosa Ideia de Darwin (Dennett, 1998, pp. 343-344). Mas ressaltamos que a questão é deveras controversa.

${ }^{16}$ Uma palavra, muito em voga nas discussões filosóficas atuais, pode resumir o conflito entre Midgley e Dawkins (e não apenas Dawkins, no mesmo The Solitary Self Midgley lança mão de críticas a Peter Atkins, Lewis Wolpert e outros): o dito "cientificismo", a crença de que a ciência é a autoridade máxima e única sobre todas as coisas, capaz de responder não apenas todos os "como?", mas todos os "por quê?". 
|322|

Mary Midgley e Richard Dawkins: semelhanças ...

Contudo, acreditamos que Midgley subestimou o poder do uso das metáforas e das analogias por parte de Dawkins, algo que lhe é característico. Como salta aos olhos quase que imediatamente, Dawkins não está dizendo que os genes são, literalmente, egoístas, mas sim que, de forma análoga ao comportamento egoísta de uma pessoa, sua dinâmica é semelhante, os genes se comportam como se fossem egoístas. O uso de analogias é uma "marca registrada" de Dawkins, desde sua tese de doutorado (Mcgrath, 2008, p. 53). Dawkins, ao formular seu conceito, já tinha em mente que não devemos encarar o gene como um agente consciente: “(...) não devemos pensar nos genes como agentes conscientes, dotados de propósitos. A seleção natural cega, entretanto, fará com que eles se comportem como se tivessem intenções, e tem sido conveniente, para abreviar, nos referirmos aos genes como se realmente tivessem intenções" (Dawkins, 2009, p. 336). A discussão parece se reduzir a uma querela, pois Midgley considera que sem essa personificação dos genes, o projeto de Dawkins é falho (enquanto Dawkins alega se tratar apenas de uma alegoria):

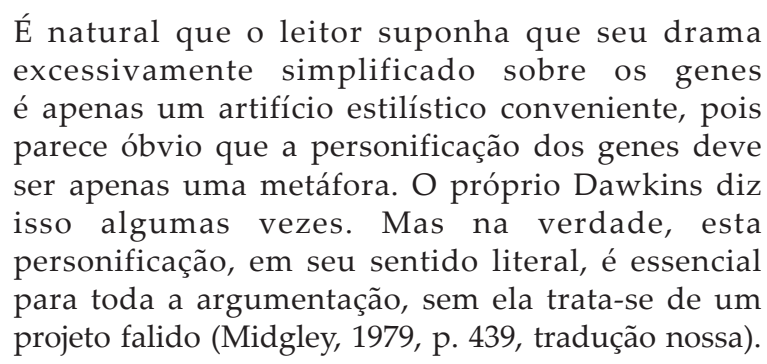

É natural que o leitor suponha que seu drama excessivamente simplificado sobre os genes é apenas um artifício estilístico conveniente, pois parece óbvio que a personificação dos genes deve ser apenas uma metáfora. O próprio Dawkins diz isso algumas vezes. Mas na verdade, esta personificação, em seu sentido literal, é essencial para toda a argumentação, sem ela trata-se de um projeto falido (Midgley, 1979, p. 439, tradução nossa).

Entretanto, em nosso entender, não é verdade que Dawkins assuma em sentido literal que os genes são egoístas. Seria ingênuo pensar que alguém considera seriamente que genes são literalmente egoístas; esta concepção é apenas uma alegoria útil à argumentação de Dawkins que visa exemplificar como a seleção natural opera na natureza, sem ter implicações morais. 
Dawkins expressa claramente, no capítulo 1 de $O$ Gene Egoísta: "não vou advogar uma moral baseada na evolução" (Dawkins, 2010, p. 40), Dawkins não está, de maneira alguma, propondo uma "base para o egoísmo filosófico" (Midgley, 1979, p. 439, tradução nossa). O egoísmo gênico a que Dawkins se refere todo o tempo não implica em nenhum sentido um egoísmo na ação das pessoas, pelo contrário, o egoísmo dos genes pode ser expresso até mesmo em termos de um altruísmo moral, como Dawkins esclarece em seu novo prefácio. Seu livro poderia tranquilamente se intitular o gene altruísta, pois ele dedica mais atenção ao altruísmo que ao egoísmo (Dawkins, 2010, p. 9) ${ }^{17}$. O livro de Dawkins nem propõe uma moral e tampouco sequer resvala no assunto: "Meu livro é sobre a evolução da vida, não sobre a ética de uma espécie particular e um tanto aberrante" (Dawkins, 1981, p. 556) diz Dawkins em sua resposta à crítica hostil de Midgley "In: Defense of Selfish Genes"18 (1981).

Ademais, a última frase do capítulo 11 de O Gene Egoísta é de grande valor para que entendamos em definitivo a questão: "Somos os únicos na Terra com o poder de nos rebelar contra a tirania dos replicadores egoístas" (Dawkins, 2010, p. 343). Ou seja, os homens, dada sua consciência complexa, podem escapar dessa "tirania" gênica, um exemplo disso: toda vez que ocorre atividade sexual e usa-se preservativo, o homem se rebelou contra seus genes (que têm por única "intenção", se perpetuar). Seus genes "queriam" prosperar por meio de um descendente, entretanto, o prazer do ato sexual foi obtido, sem a procriação. Isso soou para muitos críticos de Dawkins, especialmente os de

\footnotetext{
${ }^{17}$ Embora seja possível imaginar que Dawkins foi infeliz na escolha de seu título, visto a "carga moral" trazida pela palavra "egoísta".

${ }^{18} \mathrm{O}$ tom hostil e agressivo em que essa discussão se deu, em especial por parte de Midgley, rendeu, por parte da filósofa, o artigo "Selfish Genes and Social Darwinism" (1983), em tom de desculpas, ainda que, segundo Dennett, persista certa hostilidade (Dennett, 1998, p. 377n).
} 
$|324|$

Mary Midgley e Richard Dawkins: semelhanças ...

posição política esquerdista (que, grosso modo, têm medo do "reducionismo genético", que não asseguraria um "nós" livre para fazer a revolução) ${ }^{19}$. Obviamente isso é resultado de uma visão dicotômica de mundo, onde "livre-arbítrio" e "determinismo genético" são excludentes. Não consideram a hipótese de que sim, estatisticamente falando, os genes determinam o comportamento humano, embora ele possa ser modificado fora do nível gênico. Aqueles que não consideram essa possibilidade praticam aquilo que Dawkins chama em Desvendando o Arco-Íris de "má ciência poética":

(...) Refiro-me à ilusão de que há uma oposição simples entre o agradável e o desagradável, o social e o antissocial, o egoísta e o altruísta, o rude e o gentil; de que todos esses pares de opostos binários correspondem aos outros pares, e de que a história da controvérsia evolucionária sobre a sociedade é descrita por um pêndulo que balança de um lado para outro ao longo de um continuum entre esses opostos" (Dawkins, 2009, p. 271).

Certamente essa visão de mundo é demasiadamente limitada.

Contudo, o que dizer do comportamento dos animais objeto central de estudo da etologia - tendo em vista que os humanos podem, conscientemente, se rebelar contra os genes egoístas? Esse ramo da biologia, caro tanto a Midgley ${ }^{20}$ quanto a Dawkins não mostra que acreditar que o motor da evolução é o egoísmo é uma patente contradição? Midgley parece sugerir que sim, pois parte de seu artigo de 1979 é dedicado justamente a oferecer exemplos retirados da etologia que mostrariam que o

\footnotetext{
${ }^{19}$ Para mais detalhes, cf. Dawkins (2010), pp. 516 e 517.

${ }^{20}$ Dawkins é irônico ao considerar Midgley como alguém que domina a sociobiologia: “(...) uma ciência da qual ela aspira ser uma especialista séria”" (Dawkins, 1983, p. 557).
} 
comportamento da maior parte dos animais é altruísta ao invés de egoísta (Midgley, 1979, pp. 441-444).

A essa crítica de Midgley podemos oferecer três respostas: 1) o fato de Dawkins usar os termos em sentido exclusivamente behaviorista; 2) o fato de podermos afirmar que esse egoísmo gênico pode ser expresso na forma de altruísmo, já que não há, necessariamente, transposição do nível genético para o comportamental e 3) também se observa, no comportamento animal, a violência, até mesmo contra membros da mesma espécie.

O ponto 1 é colocado por Dawkins em sua resposta a Midgley. Ele nos diz que quando biólogos tratam de egoísmo ou altruísmo não estão falando da natureza emotiva de nenhuma espécie, tampouco dos motivos em geral, o que é, por sua vez, uma preocupação de Midgley. Estão a falar em termos estritamente behaviorísticos, é nesse sentido que uma árvore pode ser considerada como altruísta ou egoísta (Dawkins, 1983, p. 557).

O ponto 2 já havia sido mostrado por nós, cabendo apenas ressaltar que ele também é válido para todo o reino animal. Dado que Midgley discorre sobre sociobiologia, a ciência do comportamento animal, a filósofa cita exemplos retirados do mundo animal para tentar impugnar a hipótese do gene egoísta. Quanto a esse ponto, a seguinte réplica é delineada: em primeiro lugar, de acordo com Dawkins, usar os animais como modelo não é uma boa forma de fazer ciência, "Os animais não existem para ser modelos, e sim para sobreviver e reproduzir" (Dawkins, 2009, p. 273). Além disso, a observação de comportamento altruísta no mundo animal não contradiz a hipótese dos replicadores egoístas: "A posição que sempre tenho adotado é que grande parte da natureza animal é na verdade altruísta, cooperativa e até visitada por emoções subjetivas benévolas, mas isso antes resulta do egoísmo no nível genético do que o contradiz" (Dawkins, 2009, p. 274, grifos nossos).

O ponto 3, trazido à baila por Dennett, é que mesmo havendo observância do comportamento "benévolo" nos animais, isso não constitui uma regra, seu oposto também pode ser observado: 
|326|

Mary Midgley e Richard Dawkins: semelhanças ...

(...) é comum, em muitas espécies, matar irmãos (não vamos dizer assassinar, visto que eles não sabem o que fazem) é quase regra, não a exceção. (Por exemplo, quando dois ou mais filhotes de águia nascem em único ninho, o primeiro a sair da casca tende a matar o mais jovem, se conseguir, jogando para fora do ninho os ovos, ou até empurrando para fora os filhotinhos.) Quando um leão conquista uma nova leoa que ainda está amamentando filhotes de um acasalamento anterior, a primeira coisa que ele faz é matar esses filhotes para que a leoa entre mais rápido em estro. Os chimpanzés são conhecidos por travar combates mortais com outros da própria espécie, e o macaco da índia muitas vezes mata os filhotes de outros machos, para ter acesso reprodutivo às fêmeas (Hrdy, 1977) - portanto, até os nossos parentes mais próximos têm comportamentos execráveis (Dennett, 1998, p. 502).

Dennett segue a discussão nas páginas subsequentes, fornecendo mais exemplos e tratando mais a fundo da sociobiologia.

Dessa forma, acreditamos ter evanescido todas as críticas de Midgley que recaem sobre a hipótese do gene egoísta defendida por Dawkins e supomos que com a colocação dos termos corretos, Dawkins e Midgley estão do mesmo lado: aquele por uma compreensão mais ampla da realidade e da inserção do homem e dos animais nela por uma via comum, a da teoria da evolução. A despeito de qualquer discordancia marginal que podemos encontrar no pensamento dos dois.

\section{Considerações finais}

Como mostramos ao longo do artigo, Dawkins e Midgley, partindo de pressupostos semelhantes, chegam, ora a conclusões convergentes, como é o caso da rejeição da interpretação teleológica do processo evolutivo, ora divergentes, como é o caso 
da ideia de que um replicador universal, imortal e de "comportamento" egoísta é o motor da evolução. Fizemos uma defesa da posição de Dawkins no tocante ao gene egoísta, tentando ressaltar que a crítica de Midgley, ao dizer que a hipótese do replicador egoísta é reducionista, mostra que sua crítica é feita de um ponto de vista filosófico. Qualquer tentativa de explicar a realidade a partir de um único ponto de vista (i.e., reducionista) é rejeitada peremptoriamente por qualquer filósofo contemporâneo e é isso que Midgley faz, como comprova sua última obra, The Solitary Self. Midgley está marcando sua posição enquanto filósofa ao diagnosticar um suposto "cientificismo" na obra de Dawkins.

Mas ao propor o diálogo, tínhamos em mente a metáfora de Quine do cientista e do filósofo como tripulantes do mesmo barco. Ambos estão preocupados em explicar - ainda que cada um à sua maneira - ao menos parte da realidade e a inserção do homem nessa realidade, ou seja, ambos compartilham o mesmo objetivo; divergências de posição são naturais, entretanto é preciso deixar as pré-concepções de lado e trabalhar em conjunto, pois somente dessa forma nos aproximaremos das respostas às perguntas que inquietam cientistas, filósofos e o mais comum dos homens.

O fio condutor, tanto de Dawkins como de Midgley para explicar a posição do homem no cosmos é a elegante hipótese proposta por Darwin - "de um início tão simples" -, a evolução das espécies por seleção natural. Ambos admitem nosso passado animal sem maiores problemas, aliás, essa é a tônica das obras dos dois, Midgley, munida da teoria de Darwin rompe com toda uma tradição filosófica que remonta a Aristóteles e se mantém firme passando por Descartes e chegando a Kant. Dawkins faz o mesmo ao falar que a evolução não tinha de culminar no homem moderno, se isso não tivesse ocorrido, nada de errado teria se passado, todas as espécies, com as quais compartilhamos a biosfera, tiveram seus antepassados submetidos ao mesmo processo que os nossos e, no limite, somos todos descendentes 
|328|

Mary Midgley e Richard Dawkins: semelhanças ...

da mesma forma primitiva de vida, portanto, merecem igual respeito.

A proposta de Dawkins é popularizar a ciência, divulgar o método científico e fazer com que a sociedade pense por si só, sem apelar à tradição ou à autoridade - o mesmo ideal dos iluministas. Midgley, com uma abordagem diferente, quer o mesmo. A hipótese do gene egoísta é uma compreensão da maneira com que a evolução se passou e que Dawkins, em 1976, popularizou e defendeu muito bem, embora não tenha sido compreendido, ora intencionalmente, pelos seus detratores, ora sem intenção, devido a interpretações ingênuas ou desacordos semânticos (problemas estes que, confessamos, ocorreram devido à escolha ousada de Dawkins de usar a expressão gene egoísta, coisa que como o próprio Dawkins admite, não era necessária, visto que outros títulos foram cogitados para seu livro). Portanto, compreender a teoria do replicador egoísta como a apologia ao egoísmo filosófico é, como buscamos mostrar, um equívoco. As posições de Dawkins quanto à moral identificam-se com o humanismo secular e ainda com as posições éticas do filósofo Peter Singer, mas mesmo assim, toda essa discussão está distante do conteúdo de $O$ Gene Egoísta, que não é e nunca pretendeu ser um livro sobre moral, quer humana quer animal.

Embora haja uma linha bastante clara demarcando os territórios de cientistas e filósofos, isso não impede que um colabore com o outro e até concorde, especialmente quando a questão é essencialmente a mesma e o pano de fundo teórico aceito é idêntico; a despeito da clara discordância entre Midgley e Dawkins no que diz respeito ao gene egoísta, é plausível imaginar mais acordos que desacordos entre ambos, fato que também tentamos ilustrar com o exemplo, essencial em nosso entender, que mostra que ainda no terreno da própria teoria da evolução, há concordância entre os pensadores.

Nosso intuito ao mostrar um ponto de acordo e outro de desacordo entre Midgley e Dawkins (dentre outras possíveis) era mostrar que o diálogo entre ciência e filosofia é possível e mais urgente do que nunca; remeter-se à imagem de Neurath, 
a que Quine citou é, ainda hoje, de grande utilidade. Cientistas e filósofos, na tarefa de explicar o mundo e nossa interação com ele, estão não só construindo - e ao construir, explicar - um mundo como estão dentro do mesmo barco, o que indica que devem trabalhar em conjunto.

\section{Bibliografia}

BLACKMORE, S. The Meme Machine. Oxford: Oxford University Press.1999.

BUENO, M. R. S. Níveis de Seleção: Uma avaliação a partir da teoria do "gene egoísta". Dissertação - Faculdade de Filosofia, Letras e Ciências Humanas, Departamento de Filosofia, Universidade de São Paulo, São Paulo. 2008.

DAWKINS, R. Desvendando o Arco-Íris. Tradução: Rosaura Eichenberg. São Paulo: Companhia das Letras. 2009 (1998) Deus, um delírio. Tradução: Fernanda Ravagnani. São Paulo: Companhia das Letras.2006.

Escalada do Monte Improvável. Tradução: Suzana Sturlini Couto. São Paulo: Companhia das Letras.1998 (1996).

O Gene Egoísta. Tradução: Rejane Rubino. São Paulo: Companhia das Letras. 2010 (1976).

. O Relojoeiro Cego. Tradução: Laura Teixeira Motta. São Paulo: Companhia das Letras.2008 (1986).

"In Defence of Selfish Genes". Philosophy, Cambridge, v. 56 , n. 218 , pp. 556-573.1981.

DENNETT, D. A Perigosa Ideia de Darwin. Tradução: Talita Rodrigues. Rio de Janeiro: Rocco.1998.

MCGRATH, A. e MCGRATH, J. O Delírio de Dawkins. Tradução: Sueli Saraiva. São Paulo: Mundo Cristão. 2007. 
Mary Midgley e Richard Dawkins: semelhanças ...

MCGRATH, A. O Deus de Dawkins. Tradução: Sueli Saraiva. São Paulo: Shedd Publicações.2008.

MIDGLEY, M. Beast and Man. Londres: Routledge. 2002 (1978). Bestia y hombre. Tradução: Roberto Ramón Reyes Mazzoni. Ciudad del Mexico: Fondo de Cultura Económica. 1989 (1978).

. “Gene-Juggling". Philosophy, Cambridge, v. 54, n. 210, pp. 439-458. 1979.

. "Selfish Genes and Social Darwinism". Philosophy, Cambridge, v. 58, n. 225, pp. 365-377. 1983. .The Solitary Self. Durham: Acumen. 2010.

“Why memes?". In: ROSE, H. e ROSE, S. Alas, Poor Darwin: Arguments against evolutionary psychology. New York: Harmony Books, pp. 79-100. 2000.

NIETZSCHE, F. Sobre Verdade e Mentira. Tradução: Fernando de Moraes Barros. São Paulo: Hedra. 2008.

RACHELS, J. Created from Animals. Oxford: Oxford University Press.1990.

RIDLEY, M. As origens da virtude. Tradução: Berilo Vilaço Vargas. Rio de Janeiro: Record. 2000.

SAGAN, C. Pálido Ponto Azul. Tradução: Rosaura Eichenberg. São Paulo: Companhia das Letras. 1996.

SINGER, P. (ed.) Compendio de Ética. Tradução: Jorge Vigil Rubio e Margarita Vigil. Madrid: Ed. Alianza Editorial. 2004.

STENGER, V. "Is the Universe Fine-Tunned for Us?". In: EDIS, T. e YOUNG, M. (eds.). Why Intelligent Design Fails. New Jersey: Rutgers University Press. 2004.

STERELNY, K. Dawkins vs. Gould: Survival of the Fittest. Cambridge: Incon Books. 2001. 
WAIZBORT, R. "Dos Genes aos Memes: A Emergência de um Replicador Cultural". Episteme, Porto Alegre, n. 16, pp. 23-44. 2003. 